\title{
Isolasi dan Identifikasi Jamur Pada Buah Cabai Rawit (Capsicum frutescens L.) Yang Bergejala Antraknosa Dari Lahan Pertanian Di Dusun Jeruk
}

\author{
Widya Anggraeni ${ }^{1}$, Elvi Rusmiyanto P. Wardoyo ${ }^{1}$, Rahmawati ${ }^{1}$ \\ ${ }^{1}$ Program Studi Biologi, Fakultas MIPA, Universitas Tanjungpura, JL. Prof. Dr. H. Hadari Nawawi, Pontianak \\ Email korespondensi: widyawidi05@gmail.com
}

\begin{abstract}
Anthracnose is a disease that often attacks cayenne pepper (Capsicum frutescens L). This study aims to determine the species of fungus from the fruit of cayenne pepper with anthracnose symptoms. Fungal isolation was carried out using the direct plating method and fungal identification was carried out by observing the macromorphological and micromorphological characteristics of the fungi. The results showed that two fungal species were obtained, namely Colletotrichum sp (WA2) and Idriella sp. (WA3). Colletotrichum sp. (WA2) is a pathogenic fungus that causes anthracnose and Idriella sp (WA3) is a saprophytic fungus, but it is also known to be capable of being a pathogenic fungus.
\end{abstract}

Keywords : anthracnose, cayenne pepper, Colletotrichum sp. (WA2), pathogenic fungus, Idriella sp. (WA3)

\section{PENDAHULUAN}

Rasau Jaya merupakan salah satu kecamatan di Kabupaten Kubu Raya, Provinsi Kalimantan Barat yang salah satu penopang perekonomiannya berasal dari sektor pertanian. Sektor pertanian di Kecamatan Rasau Jaya meliputi pertanian tanaman kelapa (kelapa dalam, kelapa sawit dan kelapa hibrida), pertanian tanaman kopi, tanaman karet, tanaman biofarmaka, serta tanaman sayur dan buah-buahan.

Cabai rawit (Capsicum frutescens L.) merupakan salah satu tanaman buah yang dikembangkan di Kecamatan Rasau Jaya. Produksi buah cabai rawit di Kecamatan Rasau Jaya mencapai 549,50 ton dari 150 hektar lahan (Badan Pusat Statistik Kabupaten Kubu Raya, 2018). Akan tetapi, berdasarkan pengakuan petani di Dusun Jeruk mengatakan bahwa petani masih sering mengalami penurunan produksi buah cabai rawit yang disebabkan oleh adanya busuk buah patek atau yang dikenal dengan penyakit antraknosa.

Antraknosa merupakan salah satu penyakit yang sering menyerang cabai dan menyebabkan penurunan produksi cabai di Indonesia (Semangun, 2000; Syukur et al., 2009). Penyakit ini disebabkan oleh jamur yang salah satunya merupakan anggota genus Colletotrichum yang dapat mengakibatkan kerusakan serta kehilangan hasil panen hingga 100\% (Soesanto, 2006).
Menurut Dickman (1993); Than et al. (2008) dan Yudiarti (2007) spora jamur dapat disebarkan oleh angin, percikan air hujan dan menempel pada inang yang cocok yang dapat berkembang dengan cepat. Kondisi permukaan tanaman yang basah berpengaruh terhadap perkecambahan spora jamur, proses infeksi dan pertumbuhan patogen pada tanaman inang.. Umumnya, infeksi terjadi selama cuaca hangat dan basah, pada kisaran suhu $27^{\circ} \mathrm{C}$ dengan kelembapan tinggi $80 \%$ yang optimum bagi perkembangan penyakit antraknosa. Tahap infeksi jamur umumnya dimulai dari perkecambahan spora pada permukaan jaringan tanaman, menghasilkan tabung kecambah, setelah penetrasi maka akan terbentuk jaringan hifa intra dan interseluler yang menyebar melalui jaringan tanaman.

Penyakit antraknosa dicirikan dengan adanya bercak coklat kehitaman pada permukaan buah yang selanjutnya meluas menjadi busuk lunak, pada bagian tengah bercak terdapat kumpulan titik -titik hitam yang terdiri dari sekelompok seta dan konidia jamur (Agrios, 2005). Oleh karena itu, perlu diadakan penelitian untuk mengetahui jenisjenis jamur pada buah cabai rawit (Capsicum frutescens $\mathrm{L}$.) yang bergejala antraknosa dari lahan pertanian di Dusun Jeruk, Kecamatan Rasau Jaya I, Kabupaten Kubu Raya.

BAHAN DAN METODE

Waktu dan Tempat Penelitian 
Penelitian ini dilaksanakan selama dua bulan yaitu pada bulan Juli sampai dengan Agustus 2018 di Laboratorium Mikrobiologi Jurusan Biologi Fakultas Matematika dan Ilmu Pengetahuan Alam Universitas Tanjungpura, Pontianak.

\section{Bahan Penelitian}

Bahan yang digunakan dalam penelitian ini adalah media Potato Dextrose Agar (PDA), akuades, asam laktat, kloramfenikol, larutan Clorox 1\%, spirtus.

\section{Prosedur Kerja}

\section{Sterilisasi Alat}

Alat-alat yang digunakan dalam penelitian disterilisasi terlebih dahulu. Cawan petri dibungkus dengan kertas sampul dan dimasukkan ke dalam plastik serta alat-alat gelas lainnya dibungkus dalam plastik. Semua alat disterilisasi dalam autoklaf selama 15 menit pada suhu $121^{\circ} \mathrm{C}$ dan tekanan 2 atm.

\section{Pembuatan Media Potato Dextrose Agar (PDA)}

Pembuatan media PDA dilakukan dengan menggunakan 39 gram serbuk PDA yang dididihkan di dalam 1 liter akuades. Media yang telah mendidih ditambahkan kloramfenikol $10 \%$ kemudian disterilisasi dalam autoklaf pada suhu $121^{\circ} \mathrm{C}$ dan tekanan 2 atm selama 15 menit.

\section{Pengambilan Sampel}

Sampel buah cabai rawit yang bergejala antraknosa diperoleh dari lahan pertanian cabai rawit di Dusun Jeruk, Kecamatan Rasau Jaya I, Kabupaten Kubu Raya. Pengambilan sampel dilakukan dengan metode jelajah menggunakan teknik pencuplikan koleksi langsung buah cabai rawit yang bergejala antraknosa. Sampel yang telah diperoleh dimasukkan ke dalam plastic bening kemudian dibawa ke laboratorium mikrobiologi untuk dilakukan isolasi.

\section{Isolasi Jamur Pada Buah Cabai Rawit Bergejala Antraknosa}

Jamur diisolasi menggunakan metode penanaman langsung (direct plating). Buah cabai rawit yang bergejala antraknosa dibersihkan menggunakan deterjen cair dan dengan air mengalir, kemudian bagian buah yang bergejala antraknosa dipotong persegi dengan ukuran $1 \times 1 \mathrm{~cm}$. Potongan buah disterilisasi menggunakan larutan Clorox 1\%

selama 30 detik, potongan buah cabai kemudian dicuci dengan akuades steril selama lima menit dengan tiga kali ulangan, kemudian dikering anginkan di atas kertas saring. Selanjutnya, potongan buah diletakkan dalam media PDA sebanyak tiga titik (three point) dan dibiarkan sampai hifa jamur tumbuh pada media biakan. Hifa jamur yang tumbuh diambil dengan menggunakan jarum ose. Hifa ini selanjutnya dipindahkan pada media PDA yang baru untuk mendapatkan biakan murni (Tatik et al., 2013).

\section{Identifikasi Jamur Pada Buah Cabai Rawit Bergejala Antraknosa}

Isolat jamur biakan murni diidentifikasi berdasarkan karakter makromorfologis dan mikromorfologis. Identifikasi jamur mengacu pada buku Barnett dan Hunter (1972), Watanabe (1937) dan jurnal-jurnal penelitian identifikasi. Pengamatan karakteristik mikromorfologis jamur dilakukan dengan membuat preparat jamur. Biakan murni jamur dioleskan secara aseptis menggunakan ose pada gelas objek yang telah ditetesi asam laktat sebanyak 1 tetes. Identifikasi jamur secara makromorfologis meliputi warna koloni, tekstur koloni, bentuk koloni dan bentuk tepi koloni. Secara mikromorfologis meliputi: struktur hifa, organ reproduksi, bentuk spora dan konidia.

\section{Analisis Data}

Data berupa karakteristik jamur dianalisis secara deskriptif berdasarkan karakter morfologis jamur. Pengamatan karakter makromorfologis dan mikromorfologis ditampilkan dalam bentuk visual (foto), tabel dan deskripsi.

\section{HASIL DAN PEMBAHASAN}

\section{Hasil Isolasi Jamur Pada Buah Cabai Rawit Yang Bergejala Antraknosa}

Berdasarkan penelitian yang telah dilakukan, diperoleh hasil yakni dua jenis jamur dari buah cabai rawit yang bergejala antraknosa. Dua jenis jamur yang diperoleh yaitu diduga anggota spesies Colletotrichum sp. (WA2) (Gambar 1) dan Idriella sp. (WA3) (Gambar 2). Jamur anggota spesies Colletotrichum sp. (WA2) memiliki ciri yakni konidia berbentuk ovoid hingga silindris, memiliki appresorium dan askospora sedangkan jamur anggota spesies Idriella sp. (WA3) memiliki cirri yakni konidia berbentuk lunate hingga falcate dan memiliki klamidospora (Tabel 1). 
Protobiont (2019) Vol. 8 (2) : $94-100$
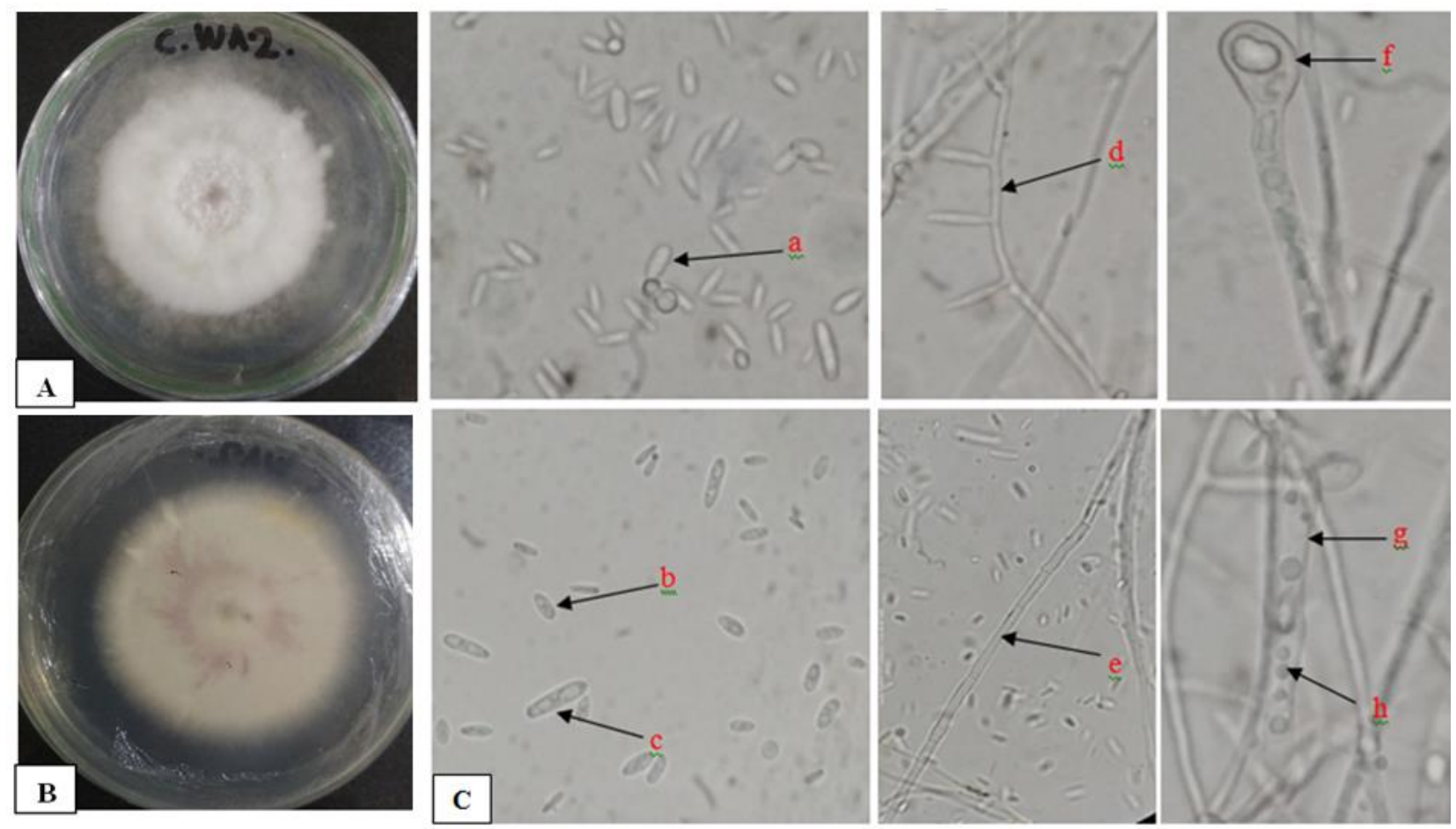

Gambar 1. Jamur anggota spesies Colletotrichum sp. (WA2) pada media PDA. Keterangan: A. Makromorfologi jamur tampak atas, B. Makromorfologi jamur tampak bawah, C. Mikromorfologi jamur: a. konidia yang berkecambah (germinasi), b. mikrokonidia, c. makrokonidia, d. konidiofor, e. hifa bersekat, f. appresorium, g. askus, h. askospora
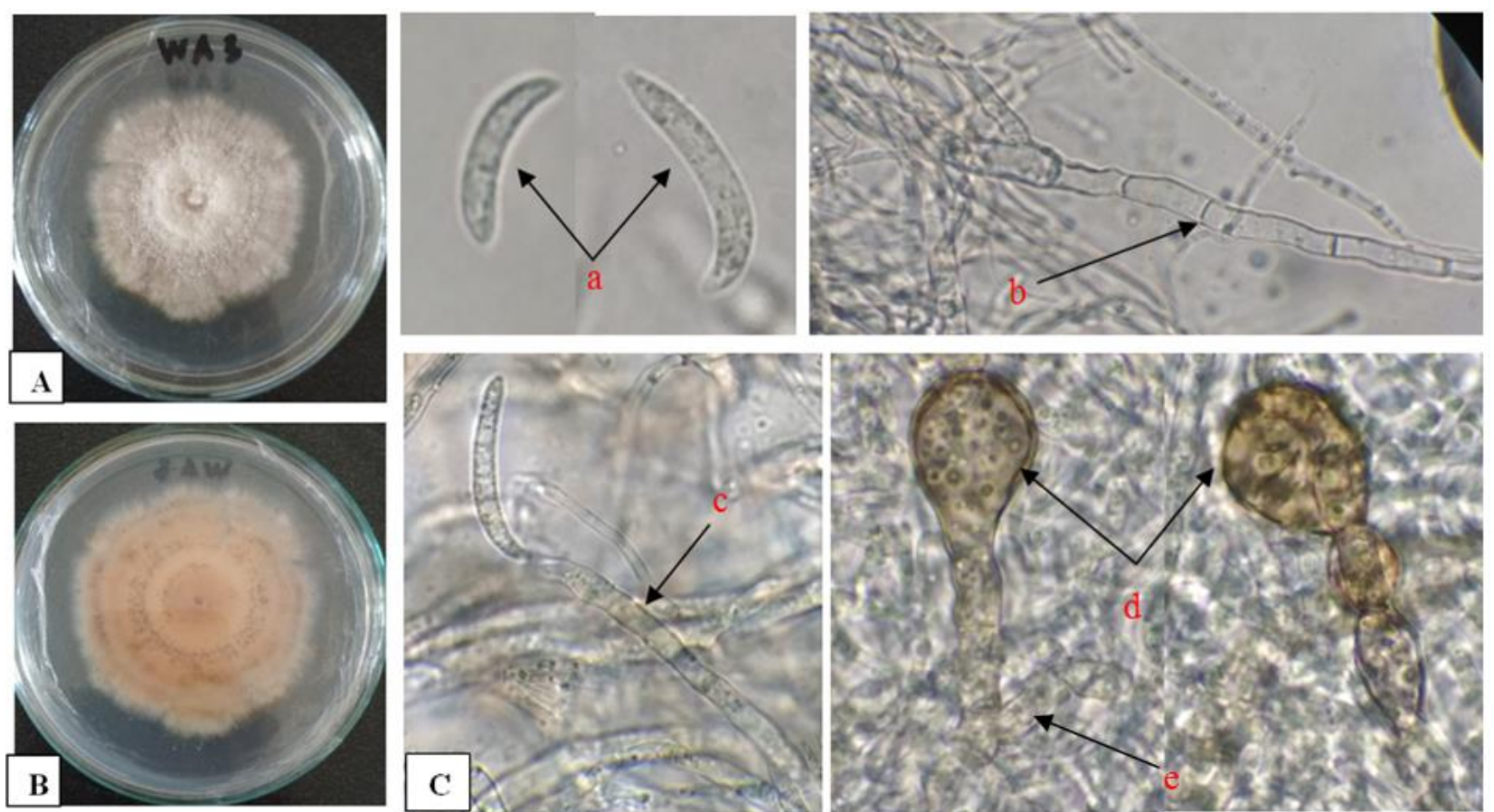

B

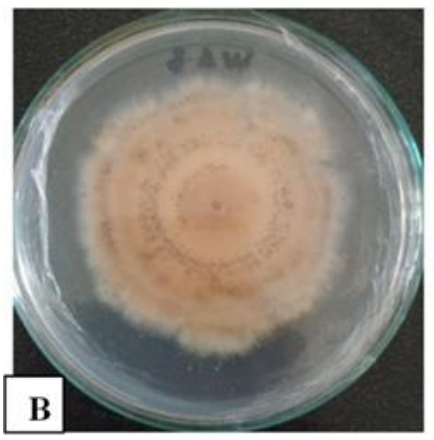

Gambar 2. Jamur anggota spesies Idriella sp. (WA3) pada media PDA. Keterangan: A. Makromorfologi jamur tampak atas, B. Makromorfologi jamur tampak bawah, C. Mikromorfologi jamur: a. konidia berbentuk lunate dan falcate, b. hifa bersekat, c. konidiofor, d. klamidospora, e. sel kaki 
Tabel 1. Karakteristik Makromorfologis dan Mikromorfologis Jamur Pada Buah Cabai Rawit yang Bergejala Antraknosa Dari Lahan Pertanian di Dusun Jeruk

\begin{tabular}{|c|c|c|c|}
\hline \multirow[b]{2}{*}{ No. } & \multirow[b]{2}{*}{ Karakteristik } & \multicolumn{2}{|c|}{ Spesies Jamur dan Kode Isolat } \\
\hline & & $\begin{array}{l}\text { Colletotrichum sp. } \\
\text { (WA2) } \\
\text { (Teleomorph: Glomerella sp.) }\end{array}$ & $\begin{array}{l}\text { Idriella sp. } \\
\quad \text { (WA3) }\end{array}$ \\
\hline
\end{tabular}

1. Makromorfologis
a. Warna permukaan koloni bagian atas
b. Warna permukaan koloni bagian bawah
c. Tekstur permukaan koloni
d. Bentuk koloni
e. Tepi koloni
f. Diameter (mm)

Putih

Putih kekriman dengan pusat koloni berwarna merah muda hingga keunguan

Halus seperti kapas

$$
\begin{gathered}
\text { Circular } \\
\text { Rata }
\end{gathered}
$$$$
\text { 59-63 mm }
$$

Ada

Hialin

Silindris dengan ujung tumpul

Ovoid

Tidak bersekat

Ada

Hialin

Tidak bercabang

Bersekat

Bersekat

Silinder tanpa askokarp

Bulat hingga ovoid

Globose (bundar)

Tidak ada

Tidak ada

Tidak ada

Putih keabu-abuan

Kuning kecokelatan

$$
\begin{gathered}
\text { Kasar } \\
\text { Irregular } \\
\text { Bergelombang } \\
55-58 \mathrm{~mm}
\end{gathered}
$$

Ada

Hialin

Lunate (Sabit) hingga

Falcate

Tidak ada

Tidak bersekat

Ada

Hialin

Tidak bercabang

Bersekat

C. Sifat tambahan
a. Struktur hifa (bersekat/tidak)
b. Bentuk askus
c. Bentuk askospora
d. Bentuk appresorium
e. Bentuk klamidospora
f. Sel kaki

\section{Bersekat}

Tidak ada

Tidak ada

Tidak ada

Clavate (Membesar di ujung) 


\section{Pembahasan}

Karakteristik Morfologis Jamur Anggota Spesies Colletotrichum sp. (WA2) Pada Buah Cabai Rawit (Capsicum frutescens L.) Bergejala Antraknosa

Jamur anggota genus Colletotrichum merupakan jamur golongan Ascomycota yang secara teleomorph dikenal juga sebagai jamur anggota genus Glomerella, dikarenakan telah ditemukannya struktur reproduksi seksual berupa askospora. Secara aseksual Colletotrichum sp. dapat memproduksi konidiospora/konidia dan secara seksual mampu memproduksi askospora (Cannon et al., 2012; De Silva et al., 2017). Jamur anggota spesies Colletotrichum sp. (WA2) yang diisolasi dari buah cabai rawit bergejala antraknosa memiliki karakteristik makromorfologis yakni koloni jamur berwarna putih dengan hifa menebal seperti kapas dan halus serta tepi koloni rata. Bagian bawah koloni jamur berwarna putih hingga krem muda dengan pusat koloni berwarna merah muda hingga keunguan (Gambar 1A-B dan Tabel 1). Hal ini sesuai dengan pernyataan Barnett dan Barry (2003), bahwa jamur anggota genus Colletotrichum memiliki karakteristik makromorfologis koloni berwarna putih dan tekstur koloni halus seperti kapas.

Secara mikromorfologis jamur anggota spesies Colletotrichum sp. (WA2) memiliki makrokonidia berbentuk silindris dengan ujung tumpul, mikrokonidia berbentuk ovoid dan bersifat hialin (Gambar 1C. b-c dan Tabel 1) Menurut Bannett \& Hunter (1972) dan Watanabe (1937) jamur Colletotrichum sp. memiliki konidia hialin dengan 1 sel, berbentuk ovoid hingga sabit. Hyde et al. (2009) menyatakan bahwa ada banyak variasi dalam bentuk konidia di antara Colletotrichum sp. C. gloeosporioides memiliki konidia lonjong dengan ujung tumpul, $C$. acutatum memiliki bentuk konidia elips hingga gelendong, $C$. dematium dengan bentuk konidia sabit dengan lengkung yang dangkal dan beberapa berbentuk gelendong yang meruncing di setiap ujungnya, C. destructivum berbentuk panjang, relatif sempit dan lurus sedikit lengkungan dan $C$. fragariae memiliki konidia dengan satu ujung membulat dan ujung lainnya meruncing.

Askospora pada jamur Colletotrichum sp. (WA2) terbungkus dalam askus yang memanjang/silinder, askospora pada jamur ini berbentuk bulat (oblate) hingga ovoid dan berwarna gelap (Gambar 1C. g-h dan Tabel 1). Menurut Sastrahidayat (2017) dan Hawksworth et al. (1995) bentuk askospora pada

Colletotrichum (Glomerella) bervariasi yakni hialin hingga gelap, selain itu askospora pada Colletotrichum memiliki bentuk lonjong/silindris (membulat di kedua ujungnya), elips/gelendong (meruncing di salah satu atau kedua ujungnya), atau melengkung (allantoid hingga suboval dan asimetris).
Karakteristik mikromorfologis lain pada Colletotrichum sp. (WA2) yakni terbentuknya perkecambahan konidia serta memiliki appresorium berbentuk bundar (globose) dan berwarna terang (Gambar 1C. a,f dan Tabel 1) Menurut Zakaria dan John (2000) perkecambahan konidia terjadi dengan munculnya tonjolan kecil tabung kecambah pada ujung konidia. Appresorium umumnya diproduksi oleh tabung kecambah atau hifa. Bentuk dari appressorium dapat dikategorikan menjadi empat jenis, yaitu bundar (globose), setengah bundar (subglobose), bercuping (lobed) dan sangat bercuping (very lobed). Appresorium dapat berwarna terang hingga coklat gelap. Berdasarkan karakter mikromorfologis jamur Colletotrichum sp. (WA2) diduga memiliki kemiripan karakteristik dengan jamur Colletotrichum gloeosporioides

(Teleomorph: Glomerella cingulata) karena memiliki kesamaan dalam bentuk konidia yakni makrokonidia berbentuk lonjong/silindris dengan ujung tumpul, mikrokonidia berbentuk ovoid. Hifa bersekat, memanjang dan bercabang serta konidiofor bersekat dan tidak bercabang. Berdasarkan penelitian Gautam (2014) Colletotrichum gloeosporioides memiliki konidia lurus, lonjong atau silindris dengan ujung bulat atau bulat dan hialin. Hifa yang diamati adalah hialin, sederhana, bersekat dan bercabang. Konidiofor panjang, hialin, bersekat, dan tidak bercabang.

\section{Karakteristik Morfologis Jamur Anggota Spesies Idriella sp. (WA3) Pada Buah Cabai Rawit (Capsicum frutescens L.) Bergejala Antraknosa}

Jamur anggota genus Idriella merupakan jamur golongan Ascomycota yang umumnya sebagai jamur saprofit dengan habitatnya yang berada di tanah dan sampah organik. Secara aseksual dapat menghasilkan konidia dan secara seksual memiliki klamidospora. Salah satu anggota spesies jamur ini diisolasi dari sampah daun Rhododendron ponticum (ARX, 1981; Restrepo et al., 2016; Wu et al., 1997).

Secara makromorfologis jamur anggota spesies Idriella sp. (WA3) memiliki bentuk koloni yang tidak beraturan 
(irregular) dengan tepi koloni yang bergelombang. Koloni jamur ini berwarna putih keabu-abuan pada permukaan koloni dan berwarna kuning kecokelatan pada bagian bawah koloni serta bertekstur kasar, miselium jamur ini lebih terbenam dibandingkan miselium pada jamur Colletotrichum sp. (Gambar 2 A-B dan Tabel 1). Menurut Restrepo et al. (2016) jamur anggota genus Idriella memiliki koloni berwarna coklat dengan miselium yang terbenam dan dangkal.

Jamur anggota spesies Idriella sp. (WA3) diisolasi dari busuk buah antraknosa pada cabai rawit yang pengisolasiannya dibedakan dengan ditemukannya jamur Colletotrichum sp. (WA2) pada busuk buah yang sama akan tetapi dari sampel yang berbeda yakni Colletotrichum sp. (WA2) dari sampel antraknosa yang pertama dan Idriella sp. (WA3) dari sampel antraknosa yang kedua. Jamur Idriella sp. (WA3) memiliki karakteristik mikromorfologis yakni konidia berbentuk lunate (sabit) hingga falcate, bersifat hialin dan tidak memiliki sekat (Gambar 2C. a dan Tabel 1) ARX, (1981) dan Restrepo et al. (2016) menyatakan bahwa jamur genus Idriella memiliki konidia pendek berbentuk lunate (sabit) hingga falcate (memanjang dengan ujung sedikit melengkung), bersifat hialin dan uniseluler.

Klamidospora pada jamur anggota spesies Idriella sp. (WA3) memiliki bentuk clavate (membesar diujung atau seperti pentungan), terdiri atas 1-3 sel, berwarna cokelat dan ada yang memiliki sel kaki ada yang tidak (Gambar 2C. d-e dan Tabel 1). Menurut Nelson dan Wilhelm (1956) spesies Idriella lunata memiliki klamidospora tersusun atas 2-3 sel dan berwarna lebih gelap, sedangkan spesies Idriella tainanensis memiliki klamidospora terdiri atas 1 sel berbentuk bulat atau clavate dengan ujung yang membesar.. Restrepo et al, (2016) juga menyatakan bahwa jamur genus Idriella memiliki klamidospora berwarna cokelat dan tersusun uniseluler atau pluriseluler.

Konidiofor pada Idriella sp.(WA3) berbentuk seperti hifa yang lurus memanjang dan bersekat, akan tetapi tidak bercabang dan hialin yang kemudian memproduksi konidia (Gambar 2C. c dan Tabel 1). Menurut Restrepo et al. (2016) sel-sel hifa interkalar dapat membentuk konidia pada pasak lateral, namun umumnya hifa juga membentuk sel konidiogen atau sel konidiogen biasanya terintegrasi pada konidiofor yang tegak lurus, bersekat dan berwarna gelap.

Jamur anggota spesies Idriella sp. juga ditemukan oleh Nelson dan Wilhelm (1956) pada akar tanaman strawberry yang bergejala busuk akar, sehingga selain bersifat saprofit, jamur ini juga bersifat patogen, sedangkan Pakdeevaraporn et al. (2005) menemukan jamur anggota spesies Colletotrichum sp. ditemukan pada buah cabai yang bergejala antraknosa. Jamur anggota spesies
Idriella sp. (WA3) dan Colletotrichum sp. (WA2) merupakan jamur patogen yang ditemukan di buah cabai rawit bergejala antraknosa dari lahan pertanian di Dusun Jeruk sehingga diduga kedua jamur tersebut memiliki peran dalam pembusukan/penyakit antraknosa pada buah cabai rawit di daerah tersebut.

\section{DAFTAR PUSTAKA}

Agrios GN, 2005, Plant Pathology, $5^{\text {th }}$ ed, Academic Press, California

ARX JA von, 1981, 'Notes on Microdochium and Idriella' Sydowia, vol. XXXIV

Badan Pusat Statistik Kabupaten Kubu Raya, 2018, Kecamatan Rasau Jaya Dalam Angka 2018, Kabupaten Kubu Raya

Barnett HL, \& Barry BH, 2003, Ilustrased Genera of Imperfect Fungi, 4 th ed, American Phythopathological Society Press, St. Paul

Barnet AL \& BB Hunter, 1972, Illustrated Genera of Imperfect Fungi, Burgers Publishing Company, Minnea Polls, Minesola

Cannon PF, Damm U, Johnston PR, Weir BS, 2012, 'Colletotrichum - current status and future directions', Studies in Mycology, no.73, hal. 181-213

De Silva DD, Crousc PW, Adesd PK and Hyde K, 2017, 'Life Styles of Colletotrichum Species and Implications for Plant Biosecurity', Fungal Biology, no.31, hal. 155-168

Dickman MW, 1993, The Fungi, Academic Press, New York

Gautam AK, 2014, 'The genera Colletotrichum: an incitant of numerous new plant diseases in India', Journal on New Biological Reports, vol 3, no 1, hal 09-21

Hawksworth DL, Kirk PM, Sutton BC, Pegler DN, 1995, Ainsworth and Bisby's dictionary of the fungi. 8th ed, Wallingford, UK: International Mycological Institute, CAB International

Hyde KD, Cai L, McKenzie EHC, Yang YL, Zhang JZ, Prihastuti H, 2009, 'Colletotrichum: a catalogue of confusion', Fungal Diversity, no.39, hal.1-17

Nelson PE \& Wihelm S, 1956, 'An Undescribed Fungus Causing A Root 
Protobiont (2019) Vol. 8 (2) : $94-100$

Rot of Strawberry', Mycologia, no.48, vol.4, hal. 547551

Pakdeevaraporn PWS, Taylor PWJ \& Mongkolporn O, 2005, 'Inheritance Of Resistance to Anthracnose Caused by Colletotrichum capsici in Capsicum', Plant Breeding, vol. 124, no. 2, hal. 206-208

Restrepo MH, JZ Groenewald, PW Crous, 2016, Taxonomic and phylogenetic re-evaluation of Microdochium, Monographella and Idriella, Persoonia, vol.36, hal. $57-82$

Sastrahidayat IR, 2017, Penyakit Tumbuhan Yang Disebabkan Oleh Jamur, Universitas Brawijaya Press, Malang

Semangun, 2000, Penyakit-Penyakit Tanaman Hortikultura, Gadjah Mada University Press, Yogyakarta

Soesanto L, 2006, Penyakit Pascapanen Sebuah Pengantar, Kanisius, Yogyakarta

Syukur MS, Sujiprihati \& Yunianti, 2009, Teknik Pemuliaan Tanaman, Departemen Agronomi dan Hortikultura, Fakultas Pertanian, Imstitut Pertanian Bogor

Tatik FH, Lahmudin L \& Hasanuddin, 2013, 'Efek Temperatur Terhadap Virulensi Jamur Colletotrichum gloeosporioides Penz. Sacc. Penyebab Penyakit Antraknosa pada Tanaman Kakao (Theobroma cacao L.)', Jurnal Online Agroteknologi, vol. 2, no. 1, hal. 411-420

Than PP, Jeewon R, Hyde KD, Pongsupasamit, Mongkolporn $\mathrm{O} \&$ Taylor PWJ, 2008. "Characterization and Pathogenicity of Colletotrichum Species Assosiated with Anthracnose on Chili (Capsicum spp.) in Thailand', Plant Pathology, vol. 57, no. 3, hal. 562572

Watanabe T, 1937, Pictorial Atlas of Soil and Seed Fungi Morphologies of Cultured Fungi and Key to Spesies, Edisi ke-2, Boca Raton London New York Washington D.C

Wu W, Sutton BC \& Gange AC, 1997, 'Notes on Three Fungicolous Fungi: Anastomyces microspores gen. et sp. nov., Idriella rhododendri sp. nov and Infundibura adhaerens', Mycol. Res, vol. 101, no. 11, hal. 1318-1322

Yudiarti T, 2007, Ilmu Penyakit Tumbuhan, Graha Ilmu, Yogyakarta

Zakaria M \& John AB, 2000, 'Morphology and Cultural Variation Among Colletotrichum Isolates Obtained from Tropical Forest Nuseries' Journal of Tropical Forest Science, vol.12, no.1, hal.1 